\title{
Redukcja emisji gazów cieplarnianych jako nowa strategia IP w branży mody
}

\section{Reduction of greenhouse gas emissions as a new IP strategy in the fashion industry}

\section{mgr Agnieszka Oleksyn-Wajda}

E-mail: a.oleksyn-wajda@lazarski.pl

\author{
dr hab. Marlena Jankowska
}

E-mail: Marlena.jankowska@us.edu.pl; nr orcid: 0000-0001-5425-9593

\begin{abstract}
Streszczenie
Szczyt klimatyczny COP24 zorganizowany w Katowicach w grudniu 2018 r. stał się przyczynkiem do debaty nad zmianami klimatycznymi. Jako godne odnotowania należy przyjąć to, że jedną z branż, które podjęły rozmowę i działania jest branża modowa. Przyjęcie Karty Działań Przemysłu Modowego na rzecz Klimatu w ramach COP24 zapoczątkowało proces integrowania się sektora modowego wokół idei ochrony klimatu. Rozwinięcie i dalsza konkretyzacja celów Karty nastąpi w pracach 6 grup roboczych, a pierwsze spotkanie grup roboczych zostanie zwołane przez UN Climate Change na początku 2019 r. Realizacja coraz bardziej rygorystycznych wymagań dotyczących warunków korzystania ze środowiska przez przemysł stanowi dla przedsiębiorców duże wyzwanie finansowe, organizacyjne i logistyczne. Z drugiej strony, prawidłowe zaplanowanie i przeprowadzenie procesu dostosowania funkcjonowania przedsiębiorstwa do nowych uwarunkowań prawnych, technicznych i technologicznych w celu sprostania wymaganiom ochrony środowiska, może okazać się dużą szansą na uzyskanie lub zwiększenie przewagi konkurencyjnej, nie tylko na lokalnym, czy regionalnym, ale często również na światowym rynku. Dostosowanie parametrów funkcjonowania linii produkcyjnej do nowych regulacji dotyczących ochrony środowiska wymaga znacznego ulepszenia istniejącej, a w wielu przypadkach pozyskania całkowicie nowej technologii. Tę z kolei chronić mogą różne prawa własności intelektualnej. Powyższe wyzwania dotykają w coraz większym stopniu także przemysłu modowego. Również w tej branży styk regulacji dotyczących ochrony środowiska z systemem ochrony własności intelektualnej okazuje się znacznie ściślejszy, niż mogłoby się z pozoru wydawać.

Znajomość prawa własności intelektualnej przez światowe marki nie zapewnia międzynarodowego sukcesu. Wynika on raczej z umiejętności stosowania nabytej wiedzy w powiązaniu prawa z psychologią sprzedaży i marketingu, czyli tzw. strategii IP. Strategie są liczne, bardzo zróżnicowane i w coraz większym stopniu wychodzą naprzeciw współczesnym wyzwaniom klimatycznym.
\end{abstract}

Słowa kluczowe: redukcja emisji gazów cieplarnianych, strategia IP, branża mody, szczyt klimatyczny.

\section{Summary}

The COP24 climate summit organized in Katowice in December 2018 has contributed to the debate on climate change. Noteworthy is the fact that one of the industries having taken up the conversation and activities is the fashion industry. The adoption of the Fashion Industry Charter for Climate Action under COP24 initiated the process of orchestrating the fashion sector around the idea of climate protection. Development and further substantiation of the Charter's goals will take place inside six working groups, the first meeting of which will be convened by UN Climate Change in early 2019.

The implementation of increasingly stringent requirements regarding environmental management conditions for industry represents a great financial, organizational and logistical challenge for entrepreneurs. On the other hand, proper planning and the process of adapting a company's operations to new legal, technical and technological conditions to meet environmental protection requirements may be a good chance to gain or increase competitive advantage, not only on a local or regional level, but also frequently on the global market. Adjustment of production line operation parameters to new regulations regarding environmental protection requires significant improvement of existing technology or, in many cases, complete replacement. The updated operation can, in turn, benefit from protection of various intellectual property rights. The above challenges, applicable to any business, have the potential to affect significantly the fashion industry in particular. Here, too, the intersection of environment protection regulatory frameworks and the intellectual property protection system turns out to be much stronger than one might expect.

Knowledge by global brands of intellectual property rights does not ensure international success. Rather, it results from the ability to apply the acquired knowledge by linking the law with the psychology of sales and marketing, i.e. 
through IP strategies. There is a multitude of such strategies and many increasingly address the contemporary climate challenges.

Key words: reduction of greenhouse gas emissions, IP strategy, fashion industry, climate summit.

Str. 24-32

\section{Bibliografia}

Buchalska, J. (2018). Prawne aspekty ochrony mody. W: K. Chałubińska-Jentkiewicz, K. Kakarenko, J. Sobczak (2018). (red.). Prawo wobec kultury i sztuki. Warszawa lex/el.

Caputa, W. (2014). Kapital klienta w budowaniu wartości przedsiębiorstwa. Warszawa.

Caputa, W. (2015). Pomiar kapitału klienta w kontekście kreowania wartości przedsiębiorstwa. Warszawa.

Chesbrough, H. W. (2003). Open innovation: The New Imperative for Creating and Profiting from Technology. Boston.

Dereń, A. M. (1998). Własność przemystowa i dobra niematerialne w obrocie gospodarczym. Bydgoszcz.

Ditty, S. Fashion Revolution written evidence to the „Sustainability of the fashion industry” inquiry. U.K. Environmental Audit Committee.

Grzegorczyk, M. (2013). Niematerialne składniki wartości przedsiębiorstwa - charakterystyka i znaczenie. Zeszyt Naukowy (131). Kolegium Zarządzania i Finansów: Studia i Prace.

Jankowska, M., Pawełczyk, M. Czarna dziura technologii w innowacyjnej gospodarce a dobra własności intelektualnej (tekst przyjęty do VI tomu Serii Geo\&IP „Intellectual Property Asset Valuation”). M. Jankowska, M. Pawełczyk, S. Augustyn M. Panfil (red.), IUS PUBLICUM Warszawa, VI tom Serii Geo\&IP I jednocześnie II tom Serii Prawo\&Moda „Intellectual Property Asset Valuation". Warszawa: IUS PUBLICUM.

Płonka, M. (2013). Etyka w modzie czyli CSR w przemyśle odzieżowym. Warszawa.

Sieńczyło-Chlabicz, J. (2013). (red.). Prawo własności intelektualnej. Warszawa.

Sopińska, A., Dziurski, P. (2018). Otwarte innowacje. Perspektywa wspótpracy i zarządzania wiedza. Warszawa.

Stelmachowski, A. (1969). Wstęp do teorii prawa cywilnego. Warszawa.

Szczepanowska-Kozłowska, K., Andrzejewski, A., Kuźnicka, A., Laskowska, A., Ostrowska, J., Ślusarek-Gajek, M., WilczyńskaBaraniak, J. (2013). Własność intelektualna. Wybrane zagadnienia praktyczne. Warszawa.

Urbanek, G. (2011). Kompetencje a wartość przedsiębiorstwa: Zasoby niematerialne w nowej gospodarce. Warszawa: Wolters Kluwer. Warmuzińska, A. (2018). Prawo mody w świetle prawa własności intelektualnej (praca magisterska. Katowice: Uniwersytet Śląski. Wolters, A., Ignatowicz, J., Stefaniuk, K., (2000). Prawo cywilne. Zarys części ogólnej. Warszawa.

Zuzek, D. K. (2017). Świadomość ekologiczna przedsiębiorców jako element zrównoważonego rozwoju. Studia Ekonomiczne. Zeszyty Naukowe Uniwersytetu Ekonomicznego w Katowicach, (326). 